\title{
TECCIENCIA
}

\section{Efficient preparation of orders in a distributor coffee company using taboo search}

\section{Preparación eficiente de órdenes en una compañía distribuidora de café usando búsqueda tabú}

\author{
Alexander Correa Espinal ${ }^{1}$, Elkin Rodríguez Velázquez² ${ }^{2}$, Rodrigo A Gómez Montoya ${ }^{3}$, José D. \\ Hernández Vahos ${ }^{4}$ \\ ${ }^{1}$ Universidad Nacional de Colombia, Medellín, Colombia, acorrea@unal.edu.co \\ ${ }^{2}$ Universidad Nacional de Colombia, Medellín, Colombia, erodrigu@unal.edu.co \\ ${ }^{3}$ Politécnico Colombiano Jaime Isaza Cadavid, Medellín, Colombia, ragomez@elpoli.edu.co \\ ${ }^{4}$ Universidad Nacional de Colombia, Medellín, Colombia, jdhernandezv@gmail.com
}

\begin{abstract}
The article aims to develop a taboo search metaheuristic to solve the routing travelling salesman problem (TSP) in the order picking process to obtain minimum distances when collecting products from the storage positions. The taboo search metaheuristic was implemented in the order picking of a coffee trading company in Antioquia, allowing the reduction of distance, time and cost of $44 \%$, what amounts to a cost savings of $\$ 825000$ a month and 825 minutes a month compared to a FLCL (Farthest Locations- Closest Location) routing strategy, currently being used by the company which allows to increase the efficiency of this operation.
\end{abstract}

Keywords: Effiency, Metaheuristic, Picking, Routing, Taboo search.

\section{Resumen}

El artículo tiene como objetivo desarrollar un metaheuristico de búsqueda tabú para resolver el problema de ruteo en la preparación de pedidos como un TSP (Travelling Salesman Problem) que permita obtener distancias mínimas para recoger los productos de las posiciones de almacenamiento. El metaheuristico de búsqueda tabú, se implementó en la preparación de pedidos en una empresa comercializadora de café en Antioquia, permitiendo la reducción de distancia, tiempo y costos del $44 \%$, lo que equivale a un ahorro de \$825000/mes y 825 minutos/mes comparado con una estrategia de ruteo PLPC (Posición más Lejana, Posición más Cercana) que actualmente utiliza la empresa, lo cual permite aumentar la eficiencia en esta operación.

Palabras clave: Búsqueda tabú, Eficiencia, Metaheuristico, preparación de pedidos, ruteo.

\section{Introduction}

The management of the finished product warehouse logistics is a process that has an impact on meeting the needs of customers in the supply chain, and for regulating the supply and demand through proper management of inventories and costs of operation [1]

In logistics, warehouse management finished product not only represents between 20 and $30 \%$ of logistics costs of the company, but has an impact on the coordination of the logistics processes of production and distribution companies, Hence the importance of proper planning, execution and control [2] [3]

Within operations management for finished product warehouse, order picking (picking), it is often considered the most important because it impacts in the attention of customer requirements, it represents between 50 and $60 \%$ of costs in the logistics process, and it is intensive in labor at non-automated warehouses. For these reasons, proper

How to cite: Correa- Espinal, A.; et al, Efficient preparation of orders in a distributor coffee company using taboo search, TECCIENCIA, Vol. 8 No. 15., 43-48, 2013, DOI: http:/dx.doi.org/10.18180/tecciencia.2013.15.5 
design and management of this operation impacts in the efficiency of warehouse management [2].

To Henn and Wäscher [4], in the management of finished product warehouse, there are consider three key decisions for proper management and efficiency as: a) assignment of storage locations, b) creation of lots and c) routing for the preparation of orders. From the raised decisions, routing often consumed the majority of resources, since it required the implementation of routes, usually with material, handling equipment and operators to collect the products, and to prepare the storage positions in order to attend the requirements of customers in the agreed conditions.

For the above reasons, this paper aims to develop a model for the preparation of routing orders using a taboo search met heuristic which permit to obtain the minimum distances to collect the goods in storage positions with a focus on efficiency.

The methodology used to achieve the objective, begins with a review of scientific and scholarly information leading to theoretically contextualize routing order preparation and to conduct an exploratory review of the state of the art. Subsequently, the structure of the taboo search met heuristic is proposed to solve the TSP (Traveling SalesmanProblem ) in the routing order picking minimum distance .

Finally, a comparison is made between the met heuristic taboo search for routing order preparation, regarding the use of the management rule PLPC store product (farthest to the nearest route point position closer to the starting point ) for the management of a warehouse for agribusiness products of packages of coffee, in order to improve the efficiency of the operation.

The article is structured in four parts. In the first part a theoretical framework and an exploratory review of the state of the art routing in order picking is presented. The second one presents the conceptual structure and the pseudo code of taboo search met heuristic for solving the TSP routing problem efficiently for preparing orders. In the third part, a comparison and analysis of the taboo search met heuristic is performed with respect to a routing rule. Finally, it presents conclusions and findings made in the research.
1.1. Theoretical Contextualization and Review of the State of the Art for Routing Orders.

The picking operation is a warehouse management, allowing collecting the products required by the clients from the storage locations using material handling equipment or people [5]

The importance of order picking in warehouse management is justified from two perspectives. The first is that impacts the satisfaction of customer requirements, allowing the preparation of orders considering references, quantities and negotiated times. [6] The second perspective relates to a preparation operation for efficient order picking, regarding resource utilization and operating costs. For these reasons, proper planning, execution and control of the preparation of orders is necessary.

To Bartholdi and Hackman [1], the picking operation represents about $55 \%$ of the warehouse management, and the percentage of time consumed by some of their activities, they are presented below (see Table 1).

Table 1. Percent of time consume in the activities of

\begin{tabular}{|c|c|}
\multicolumn{2}{|c}{ picking } \\
\hline Activity & $\%$ of time picking \\
\hline Routing & $55 \%$ \\
\hline Search & $15 \%$ \\
\hline Removing & $10 \%$ \\
\hline Document management and other activities & $20 \%$ \\
\hline
\end{tabular}

From the activities of picking, routing often represents the activity that consumes more resources with $55 \%$, as this requires the use of resources such as material handling equipment, labor and Information and Communications Technologies (ICT) to collect the products from storage locations that are located in different parts of the warehouse management. For these reasons becomes important, the establishment of efficient routes for the preparation of orders that allow the proper use of the resources of the logistics process.

The routing order preparation consist of establish a sequence of minimum distance or time to collect orders placed in the assigned storage locations using equipment for handling material [7] [8] . Additionally, it should be noted that the routing of picking impact the satisfaction of the needs of customers, hence, the requirement of the proper design [8].

Below, a typical route picking in warehouse management of blocks conform by aisles is shown (see Figure 1). 


\section{TECCIENCIA}

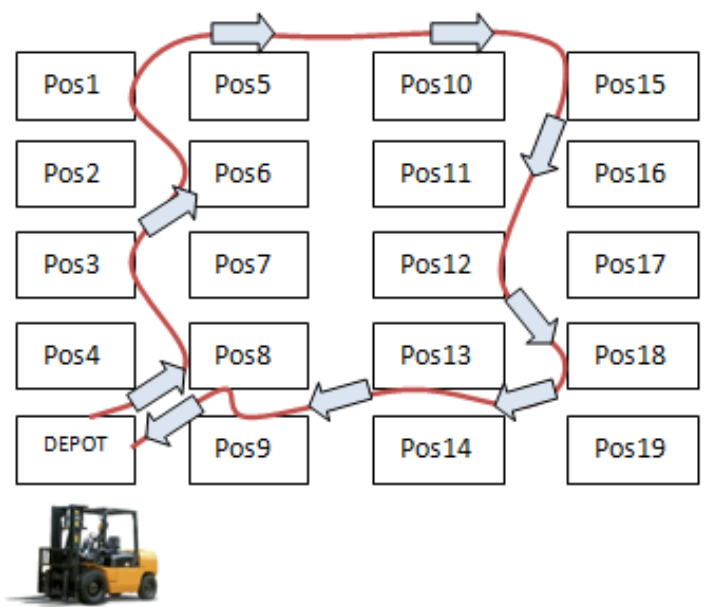

Figure 1. Route picking

The routing problem of picking for warehouse management shaped block ( see Figure 1) can be modeled mathematically as a TSP [8] problem, as the route usually begins and ends in the same physical place called ( depot ), a storage position should be visited only once to collect the products of customer orders .

From a review of the state of the art, it is identified that to solve the routing problem of picking as a TS, have been proposed exact algorithms for stores with a limited number of corridors [8], met heuristics of taboo search [8] [9] [4] or genetic algorithms [10] that allow to obtain minimum distances to collect from the storage positions.

Regarding the use of met heuristics Kulak, Sahin and Taner [9] and Henn and Wäscher [4] develop a routing model for order picking using taboo search for obtaining minimum distance route. Meanwhile, Tsai, Liou, Huang [10] developed a genetic algorithm for minimum distance routes for the preparation of order, regardless of the use of equipment for handling materials. One limitation of the reviewed met heuristics is that the efficiency of routing orders as a factor of impact in the productivity of management finished product is not consider not either measure, which is considered a limited consumption approach for the consume of time and costs that often represent this operation.

For these reasons, is identify the opportunity to research, to modeling a taboo search met heuristic to solve the routing problem of picking as a TSP, that permits to measure the efficiency of the operation, and the impact on productivity of management of the finished products in the warehouse.

\section{Modeling of the met heuristic taboo search to solve the problem of routing tsp orders.}

To solve the TSP routing problem of picking, a taboo search met heuristic which allows obtaining a sequence of storage locations to visit in order to pick the products ordered by customers in the shortest possible distance is modeled.

Then, a mathematical model for the TSP routing problem of picking orders is solved by using a taboo search met heuristic.

The objective function (1) seeks picking routes of minimum distance. For its part, the constraints (2) and (3) ensure that storage positions $\mathrm{i}$ and $\mathrm{j}$, which are visited once in each route to collect the products of customer orders. Constraints (4) prevent sub-tours in the original set of $\mathrm{N}$ cities.

The development of taboo met heuristic to solve the TSP routing problem for picking at minimum distance, has components as: initial route (initial solution), generator of neighborhood routes, taboo list, objective function. Then the proposed components are described (see Table 2).

Table 2. Met heuristic Components of search taboo routing picking orders

\begin{tabular}{|c|c|}
\hline $\begin{array}{c}\text { objective } \\
\text { Function }\end{array}$ & $\begin{array}{c}\text { Let's assess and record the distance of the route } \\
\text { picking looking to get the minimum distance. }\end{array}$ \\
\hline initial solution & $\begin{array}{c}\text { Initial preparation route requests, which is used } \\
\text { as seed to implement taboo search met heuristic }\end{array}$ \\
\hline $\begin{array}{c}\text { Generator } \\
\text { neighbors }\end{array}$ & $\begin{array}{c}\text { Manage the movement of taboo search, in order } \\
\text { of listing feasible neighboring solutions that are } \\
\text { evaluated in the objective function. }\end{array}$ \\
\hline taboo list & $\begin{array}{c}\text { This registers a list of routes picking that have } \\
\text { been evaluated and that are restricted for a } \\
\text { number of iterations (tenure). }\end{array}$ \\
\hline
\end{tabular}

The taboo search met heuristic to solve the TSP routing problem picking minimum distance, is modeled computationally using the Framework OpenTS developed in JAVA $®$ programming language. Then the pseudo code of taboo search met heuristic modeling is shown (see Figure 2).

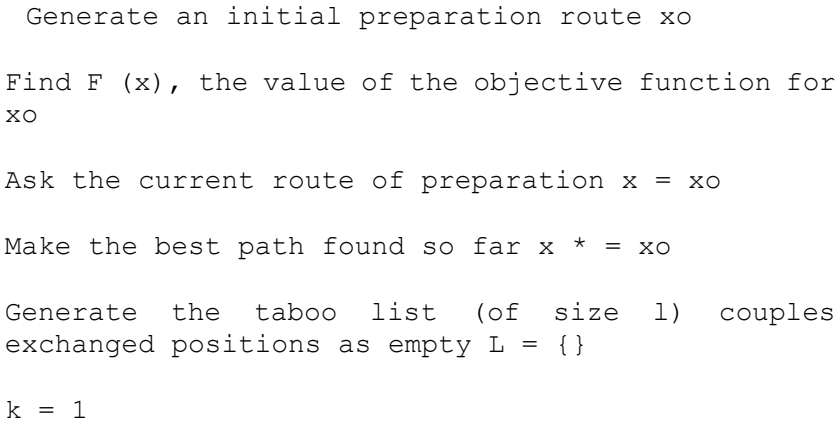




\section{TECCIENCIA}

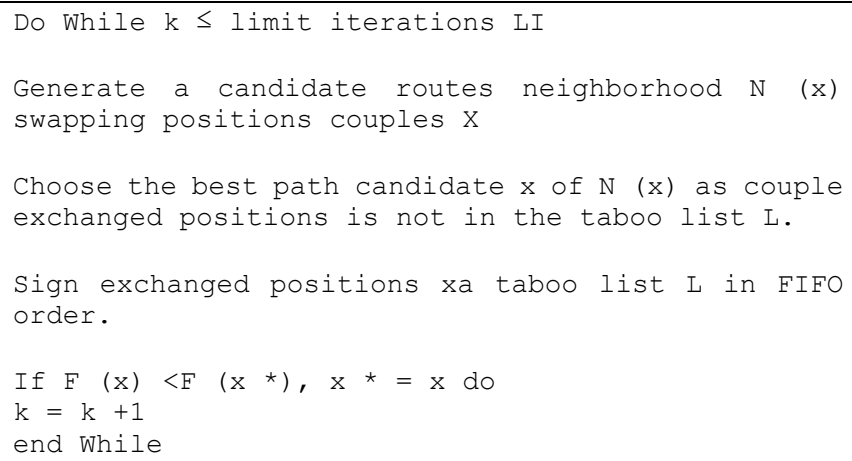

Figure 2. Pseudo code taboo search met heuristic

The taboo search met heuristic to solve the TSP problem, generates an initial route $(\mathrm{x} 0)$ that allows to collect the products ordered by customers along with the distance it takes, $\mathrm{F}$ (xo ) and becomes the current solution $\mathrm{x}$, which is becomes the best solution found so far $\mathrm{x}$ *

Then initialized as empty taboo list $\mathrm{L}$ of size 1 keeping exchanged in the past interactions 1 positions. Subsequently, a neighborhood picking routes around the route $\mathrm{x}(\mathrm{N}(\mathrm{x})$ in order to establish a set of candidate routes. Of these, the best solution is selected such that the exchanged positions that led to it are not in the taboo list.

This solution becomes the new current xy preparation route; the couple exchanged positions enter in the taboo list $\mathrm{L}$ in order to restrict such exchange during the interactions. In case that the new solution route takes place in a distance less than $\mathrm{x}^{*}$, it becomes the new best route found, $\mathrm{x} *$. This procedure is performed until the maximum number of interactions LI are reach.

To run the framework OpenTS routing taboo search that contains the pseudo code described, Net beans IDE 7.0.1, is available for Windows on a computer with Intel Pentium 4 $3.20 \mathrm{GHz}$ processor and $1 \mathrm{~GB}$ RAM. Being obtained using time execution of 2 seconds to run the problem addressed which is described in the next section.

\section{Case study of implementation met heuristic tabu search for the routing of preparation of orders in a deposit of coffee}

A company located in the west of Antioquia (Colombia) dedicated to the collection and marketing of green coffee in loads of $125 \mathrm{~kg}$, which is sold to domestic and international markets, was selected.
The company has a warehouse of $4.000 \mathrm{~m} 2$ in which the operations of reception, accommodation in storage locations on pallets, inventory management, order preparation and delivery are developed.

The picking operation aims to collect loads of coffee storage positions in the shortest distance or time as possible, in order to attend the requirements in the agreed conditions. Below the activities and resources of the picking operation of preparation for the company in study are presented (see Table 3).

Table 3. Characterization of preparing routes for a coffee company

\begin{tabular}{|c|c|c|}
\hline Objetive & \multicolumn{2}{|c|}{$\begin{array}{l}\text { Prepare customer orders traveling the shortest } \\
\text { possible distance }\end{array}$} \\
\hline Responsable & \multicolumn{2}{|c|}{ Director of Logistics and Operations } \\
\hline \multicolumn{3}{|l|}{ Activities } \\
\hline \multicolumn{3}{|c|}{ Process customer orders } \\
\hline \multicolumn{3}{|c|}{ Develop preparedness checklist (picking list) } \\
\hline \multicolumn{3}{|c|}{ Set Route for picking } \\
\hline \multicolumn{3}{|c|}{ Locate the area office products } \\
\hline \multicolumn{2}{|c|}{ Resources } & $\begin{array}{l}\text { Information and Communications } \\
\text { Technologies }\end{array}$ \\
\hline \multicolumn{2}{|c|}{$\begin{array}{l}\text { - Operators } \\
\text { - Dock loading and } \\
\text { unloading } \\
\text { - Pallet }\end{array}$} & $\begin{array}{l}\text { Management software for inventory } \\
\text { management and ordering }\end{array}$ \\
\hline
\end{tabular}

To model the routing problem TSP preparing minimum distance for the coffee trading company, is taking as a base the list of orders which considers the reference coffee, quantity and storage positions where the corresponding product requested by the domestic customers is located (see Table 4).

Table 4. Orders to prepare

\begin{tabular}{|c|c|c|c|c|c|c|c|}
\hline Name & $\begin{array}{c}\text { Storage } \\
\text { Unit }\end{array}$ & packing & $\begin{array}{c}\text { Amount } \\
\text { to gather }\end{array}$ & \multicolumn{4}{|c|}{$\begin{array}{c}\text { Storage } \\
\text { locations }\end{array}$} \\
\hline Coffee special rate 90\% & Unit & Bundle & 10 & 1 & 2 & 3 & 4 \\
\hline Special Café 95\% & Unit & Bundle & 8 & 5 & 6 & 7 & 8 \\
\hline Special Café 85\% & Unit & Bundle & 4 & 9 & 10 & 11 & 12 \\
\hline
\end{tabular}

To measure the efficiency of order picking of coffee trading company, indicators for measuring distance, time and cost of the route are used (see Table 5).

Table 5. efficiency indicators preparing coffee company marketing orders

\begin{tabular}{|c|c|}
\hline $\begin{array}{c}\text { Route distance } \\
\text { picking }\end{array}$ & $\begin{array}{c}\text { The distance traveled in meters }(\mathrm{m}) \text { to collect the } \\
\text { packages of coffee using a strategy of developing } \\
\text { specific orders is measured. }\end{array}$ \\
\hline Time & $\begin{array}{c}\text { The time of the route is estimated as measured: } \\
\text { Time }(\mathrm{T})=\frac{m}{v} \\
\text { m: meters traveled route } \\
\text { v: hand pallet average speed is a constant } 0.10 \mathrm{~m} / \mathrm{s}\end{array}$ \\
\hline Costs & $\begin{array}{c}\text { In the finished product warehouse, it has a } \\
\text { standard cost of } \$ 1000 / \text { min for the picking } \\
\text { operation }\end{array}$ \\
\hline
\end{tabular}




\section{TECCIENCIA}

\subsection{Comparison of strategies PLPC (furthest position} from Closer Point beginning of route) and Taboo Search met heuristic for Solving TSP Routing Problem.

Next, a quantitative comparison of the use of the rule PLPC (nearest to farthest to the way point position start position) and taboo search met heuristic to solve the routing problem TSP minimum distance is performed in order, to measure the indicators efficiency of each one of the strategies in the order picking in warehouse management of the commercialize company of coffee.

Strategy 1 routing PLPC (farthest position, closest position): To implement this routing strategy, the first step is the identification of the storage locations where the packages of coffee are located in order to attend customer orders. Subsequently, the route is arranged starting from the storage position which is located farthest from the initial position of the collection order picking. In this strategy, a clerk goes over each aisles of the warehouse where the Coffee packages are located, and the route starts and ends at the same initial position of storage (depot).

The route designed for order picking strategy with PLPC is shown below:

$$
x:\{1,12,11,10,9,8,7,6,5,4,3,2,1\}
$$

The implementation of PLPC routing strategy for the preparation of orders, generates a distance to travel $37.5 \mathrm{~m}$ to collect packages of coffee and meet the requirements of customers.

Strategy 2 - TSP routing picking using the taboo search met heuristic: The second strategy to solve the TSP routing problem for picking the coffee trading company uses the taboo search met heuristic developed computationally in frameworkOpenTS, giving a sequence of storage locations to visit to collect the packages of coffee requested by customers in the minimum possible distance.

The picking route running with OpenTS framework is evaluated in three different scenarios taboo list size (see Table 6), which are set as reference values for these met heuristics and experienced team modelers. For each scenario, 100 interactions are executed, that permit to obtain the following routes of minimum distance to collect the references of coffee:
Table 6. Results of TSP routes picking with the minimum different distance list sizes taboo.

\begin{tabular}{|c|c|c|}
\hline Tabu List Size & $\begin{array}{c}\text { Distance } \\
\text { (meters) }\end{array}$ & Route \\
\hline 3 & 28,5 & {$[0,1,2,3,4,5,8,7,6,9,10,11,0]$} \\
\hline 5 & 27 & {$[0,1,2,3,4,5,8,6,7,11,10,9,0]$} \\
\hline 7 & 24 & {$[0,1,2,5,3,4,7,6,8,11,10,9,0]$} \\
\hline 10 & 21 & {$[0,1,2,5,3,4,7,8,11,10,9,6,0]$} \\
\hline
\end{tabular}

With the TSP routes of picking different sizes from the taboo list, the distance to pick up the packages of coffee is 25.13 $\mathrm{m}$ with a deviation of $3.33 \mathrm{~m}$.

For practical purposes in the finished product warehouse distributor of coffee, the TSP route chosen is calculated with the taboo list of size 10 :

$$
x\{0,1,2,5,3,4,7,8,11,10,9,6.0\}=21 \mathrm{~m}
$$

This TSP minimum distance route allows collecting the 22 packages of coffee of the three references requested by the customers. At a distance of $21 \mathrm{~m}$, considering that this approach seeks to improve the efficiency use of resources, reduction of costs and time in the logistics operations.

\subsection{Measurement and Comparison of Efficiency Strategies for Routing of Picking.}

Once that the strategies of PLPC and taboo met heuristic to solve the TSP routing problem for picking are implemented, a comparison of efficiency indicator is made for both compared strategies that are performed ( see Table 7).

Table 7. Comparison efficiency indicators of routing strategies for picking

\begin{tabular}{|c|c|c|}
\hline & PLPC & $\begin{array}{c}\text { Tabu search } \\
\text { metaheuristic }\end{array}$ \\
\hline Route distance picking & $37,5 \mathrm{~m}$ & $21 \mathrm{~m}$ \\
\hline Time / Route & 375 seconds & 210 seconds \\
\hline Costs / route & $\$ 6250$ & $\$ 3500$ \\
\hline
\end{tabular}

Analysis indicators, identifies that the routing strategy picking with taboo search, is more efficient than the PLPC strategy, since a $44 \%$ in the distance, time and cost is obtained, which, evidence a contribution to increasing the efficiency and productivity of order picking in the warehouse of finished products of the trading coffee company. Relating to costs, an estimated savings of $\$$ $2750 /$ rout, is accomplish; bearing in mind that 300 routes per month are running, a savings of $\$ 82,500$ would be reached equivalent to $825 \mathrm{~min} / \mathrm{month}$, which can contribute to the efficiency of the operation and management of the finished product warehouse. 


\section{Conclusions}

The need for a proper design and management of the picking operation is identified, as it represents between 50 and $60 \%$ of the operating costs for managing the finished product warehouse, and impacts on meeting the needs of customers on the agreed conditions. Even within the activities of picking, routing, consumes about $55 \%$ of the operation time, hence the importance of strategies that allow this to run efficiently.

The article states that the problem of routing the picking, can be modeled as a TSP, since the operation begins and ends in the same warehouse site (depot), and it should be visited only once by destination to the position storage where products are located to pick up orders from customers. Additionally, after reviewing the literature on the TSP problem routing picking, it can be solved with optimization models and met heuristics looking forward to achieve minimum operating distances.

From the implementation of taboo search meta heuristic to solve the TSP routing problem of picking the coffee at the trading company in southwestern Antioquia, it is clear that this offers the greatest efficiency more than PLPC strategy (Farther position closer position) of routing, because the distance is reduced by $44 \%(16.5 \mathrm{~m})$ as well as time and cost of preparation of orders for pick up packages of coffee required by customers.

Additionally, it contributes to the state of the art, developing an approach for routing order picking efficiency measurement, which, had not been identified in an exploratory review of the literature. It has to be considered that the company carries out an average of 300 picking operations per month, for a total savings of $\$ 825,000$, equivalent in time to 825 minutes / month, which gives a great impact in the efficiency of the operation, and the warehouse of finished product for marketing the coffee.

As future work, we consider the inclusion of multiple variables, such as more vehicles with different types of loads, and distribution warehouses which establish efficient routing strategies for picking, that will impact the productivity of the warehouse management finished product.

\section{Acknowledgements}

At the National University of Colombia for the financial support in the implementation of the Research Project Quipu 202010011024, code named "Development of a system for warehouse management (Warehouse Management System) with met heuristics to support operating decisions and control centers distribution."

Laura Velez Calle research assistant GIMGO group of Systems and Computer Engineering, National University of Colombia, Medellin.

\section{References}

[1] J. Bartholdi y S. Hackman, Warehouse \& Distribution science. Release 0.95, Atltanta: School of industrial Systems Engineering., 2011.

[2] E. Frazelle y S. Sojo, Logística de Almacenamiento y Manejo de Materiales de Clase Mundial, Bogotá: Grupo Editorial Norma, 2006.

[3] H. Min, «Application of a decision support system to strategic warehousing decisions,» International Journal of Physical Distribution \& Logistics Management, vol. 39, $\mathrm{n}^{\circ}$ 1, pp. 270-281, 2009.

[4] S. Henn y G. Wäscher, «Tabu search heuristics for the order batching problem in manual order picking systems,» European Journal of Operational Research, vol. 222, nº 3, pp. 484-494, 2012.

[5] J. V. D. Berg, Integral Warehouse Management: The Next Generation in Transparency, Amsterdam: 2007, 2007.

[6] S. Henn, S. Koch, K. Doerner, C. Strauss y G. Wäscher, «Metaheuristics for the order batching problem in manual order picking systems,,» Bussines Research. Official Open Access Journal of VHB, vol. 3, $\mathrm{n}^{\mathrm{o}}$ 1, pp. 1-24, 2010.

[7] R. Koster y E. Van Der Poort, «Routing orderpickers in a warehouse: a comparison between optimal and heuristic solution,» IIE Transactions, vol. 30, nº 5, pp. 469-480, 1998.

[8] C. Theys, O. Bräysy, W. Dullaert y B. Raa, «Using a TSP heuristic for routing order pickers in warehouses,» European Journal of Operational Research, vol. 200, n 1, pp. 755-763, 2010.

[9] O. Kulak, Y. Sahin y M. Taner, «Joint order batching and picker routing in single and multiple-cross-aisle warehouses using cluster-based tabu search algorithms,» Flexible services and manufacturing journal, vol. 24, no 1, pp. 52-80, 2012.

[10] C. Tsai, J. Liou y T. Huang, «Using a multiple-GA - method to solve the batch picking problem: considering travel distance and order due time,» International Journal of Production Research, vol. 46, $\mathrm{n}^{\circ} 22$, pp. 6533-6555, 2008.

[11] J. L. a. T. C.Tsai, «Using a multiple-GA method to solve the batch picking problem: considering travel distance and order due time,» International Journal of Production Research, vol. 46, pp. 6533-6555, 2008 . 